\section{International Organization for Standardization (ISO)}

Established in 1947, the International Organization for Standardization is a non-governmental federation of national standards bodies from 157 countries worldwide, one from each country. ISO's work results in international agreements which are published as International Standards. The first ISO standard was published in 1951 with the title 'Standard reference temperature for industrial length measurement'.

Some 15,400 ISO International Standards are available on subjects in such diverse fields as information technology, textiles, packaging, distribution of goods, energy production and utilization, building, banking and financial services. ISO standardization activities include the widely recognized ISO 9000 family of quality management system and standards and the ISO 14000 series of environmental management system standards. Standardization programmes are now being developed in completely new fields, such as food safety, security, social responsibility and the service sector.

Mission. To promote the development of standardization and related activities in the world with a view to facilitating the international exchange of goods and services, and to developing co-operation in the spheres of intellectual, scientific, technological and economic activity.

Headquarters: 1 chemin de la Voie-Creuse, Case postale 56, CH-1211 Geneva 20, Switzerland.

Website: http://www.iso.org

Secretary-General: Rob Steele (New Zealand).

\section{International Organization of the Francophonie}

The International Organization of the Francophonie represents 70 countries and provinces/regions (including 14 with observer status) using French as an official language. Objectives include the promotion of peace, democracy, and economic and social development, through political and technical co-operation. The Secretary-General is based in Paris.

Members. Albania, Andorra, Belgium, Benin, Bulgaria, Burkina Faso, Burundi, Cambodia, Cameroon, Canada, Canada-New Brunswick, Canada-Quebec, Cape Verde, Central African Republic, Chad, Comoros, Democratic Republic of the Congo, Republic of the Congo, Côte d'Ivoire, Djibouti, Dominica, Egypt, Equatorial Guinea, France, French Community of Belgium, Gabon, Greece, Guinea, Guinea-Bissau, Haiti, Laos, Lebanon, Luxembourg, Macedonia, Madagascar, Mali, Mauritania, Mauritius, Moldova, Monaco, Morocco, Niger, Romania, Rwanda, St Lucia, São Tomé e Príncipe, Senegal, Seychelles, Switzerland, Togo, Tunisia, Vanuatu, Vietnam. Associate Members. Armenia, Cyprus, Ghana. Observers. Austria, Croatia, Czech Republic, Georgia, Hungary, Latvia, Lithuania, Mozambique, Poland, Serbia, Slovakia, Slovenia, Thailand, Ukraine.

Headquarters: 28 rue de Bourgogne, 75007 Paris, France.

Website: http://www.francophonie.org (limited English)

Secretary-General: Abdou Diouf (Senegal).

\section{International Road Federation (IRF)}

The IRF is a non-profit, non-political service organization whose purpose is to encourage better road and transportation systems worldwide and to help apply technology and management practices to give maximum economic and social returns from national road investments.

Founded following the Second World War, over the years the IRF has led major global road infrastructure developments, including achieving $1,000 \mathrm{~km}$ of new roads in Mexico in the 1950s, and promoting the Pan-American Highway linking North and South America. It publishes World Road Statistics, as well as road research studies, including a 140-country inventory of road and transport research in co-operation with the US Bureau of Public Roads.

Headquarters: 2 chemin de Blandonnet, CH-1214 Vernier/GE, Switzerland.

Website: http://www.irfnet.org

Director-General (Brussels): Christophe Nicodème (Belgium).

Director-General (Geneva): Sibylle Rupprecht (Switzerland).

Director-General (Washington, D.C.): C. Patrick Sankey

(USA).

\section{International Seabed Authority (ISA)}

The ISA is an autonomous international organization established under the UN Convention on the Law of the Sea (UNCLOS) of 1982 and the 1994 Agreement relating to the implementation of Part XI of the UNCLOS. It came into existence on 16 Nov. 1994 and became fully operational in June 1996.

The administrative expenses are met from assessed contributions from its members. Membership numbered 160 in Feb. 2010; the budget for the biennium 2007-08 was US $\$ 11,782,400$.

The UNCLOS covers almost all ocean space and its uses: navigation and overflight, resource exploration and exploitation, conservation and pollution, fishing and shipping. It entitles coastal states and inhabitable islands to proclaim a 12-mile territorial sea, a contiguous zone, a 200-mile exclusive economic zone and an extended continental shelf (in some cases). Its 320 Articles and nine Annexes constitute a guide for behaviour by states in the world's oceans, defining maritime zones, laying down rules for drawing sea boundaries, assigning legal rights, duties and responsibilities to States, and providing machinery for the settlement of disputes.

Organization. The Assembly, consisting of representatives from all member states, is the supreme organ. The 36-member Council, elected by the Assembly, includes the four largest importers or consumers of seabed minerals, four largest investors in seabed minerals, four major exporters of the same, six developing countries representing special interests and 18 members from all the geographical regions. The Council is the executive organ of the Authority. There are also two subsidiary bodies: the Legal and Technical Commission (currently 25 experts) and the Finance Committee (currently 15 experts). The Secretariat serves all the bodies of the Authority and under the 1994 Agreement is performing functions of the Enterprise (until such time as it starts to operate independently of the Secretariat). The Enterprise is the organ through which the ISA carries out deep seabed activities directly or through joint ventures.

Activities. In July 2000 the ISA adopted the Regulations for Prospecting and Exploration for Polymetallic Nodules in the 